\title{
Joint Statement of the Ad-hoc Committee of the Korean Society for Preventive Medicine and the Korean Society of Epidemiology on Tobacco Lawsuits on the causal link between tobacco smoking and lung cancer
}

\author{
Ad-hoc Committee of the Korean Society for Preventive Medicine and the Korean Society of \\ Epidemiology on Tobacco Lawsuits
}

\section{PROCESS AND BACKGROUND}

The National Health Insurance Service (NHIS) has filed a damage suit against tobacco producers KT\&G, Philip Morris Korea, and BAT Korea (hereafter referred to as "Tobacco Lawsuit"). In the course of the ongoing lawsuit, heated debates are underway regarding the causal relationship between tobacco smoking and lung cancer. The affected individuals of this class action are those with one of three lung cancer types (small cell lung cancer, squamous cell lung cancer, and squamous cell laryngeal cancer), having a smoking history of 20 pack-years or more, and having smoked for 30 years or more.

Given the nature of tobacco smoking as an very important risk factor threatening public health, the Korean Society for Preventive Medicine (CEO:Won-Chul Lee) and the Korean Society of Epidemiology (President: Bo Youl Choi), whose core values lie in disease prevention and health promotion, have paid particular attention to the Tobacco Lawsuit, especially to the raised debates about the causal relationship between smoking and lung cancer.

Under the current circumstances, in which the plaintiff (NHIS) and the defendants (tobacco companies) repeatedly mention the value and role of epidemiologic studies in evaluating the causal connection between environmental risk factors and lung cancer in their respective briefs submitted to the court, the Korean Society for Preventive Medicine and the Korean Society

This article is also being simultaneously published in Journal of Preventive Medicine and Public Health by the Korean Society for Preventive Medicine.

Received: Jun 15, 2015, Accepted: Jun 15, 2015, Published: Jun 15, 2015 This article is available from: http://e-epih.org/ (C) 2015, Korean Society of Epidemiology

(C) This is an open-access article distributed under the terms of the Creative Commons Attribution License (http://creativecommons.org/licenses/by/3.0/), which permits unrestricted use, distribution, and reproduction in any medium, provided the original work is properly cited. of Epidemiology, whose key discipline is epidemiology, have come to have deep concerns and feel the urgent need for a position statement regarding this issue.

To address this issue, the Korean Society for Preventive Medicine and the Korean Society of Epidemiology agreed to jointly constitute an "Ad-hoc Committee of Korean Society for Preventive Medicine and the Korean Society of Epidemiology on Tobacco Lawsuits" (hereafter referred to as "ad-hoc Committee"), whereupon the ad-hoc Committee was constituted with area experts (cf. the annexed list of the ad-hoc Committee members).

After two seminars, continuing discussions by email, drafting a raw version of the statement with comments from ad-hoc Committee members, and coming to an agreement on the language and content, the ad-hoc Committee has drafted a joint statement. After obtaining approvals from the Korean Society for Preventive Medicine and the Korean Society of Epidemiology as well as their respective boards, the ad-hoc Committee publishes this Joint Statement on behalf of both societies.

\section{FOCAL POINT OFTHE "CAUSAL LINK BETWEEN SMOKINGAND OCCURRENCE OF LUNG CANCER"}

In the aforementioned tobacco lawsuit, debates have been held about the role of epidemiology in disease causality in the briefs based on an incorrect understanding of the value and role of epidemiological studies. As epidemiology constitutes the scientific basis of the Korean Society for Preventive Medicine and the Korean Society of Epidemiology, we regard it as the academic and social duty of both societies and the ad-hoc Committee to provide a correct understanding of the role of epidemiology in disease causality.

After reviewing the briefs submitted by the plaintiff (NHIS) and defendants (tobacco companies), the ad-hoc Committee 
viewed the following three perspectives of the "causal link between smoking and lung cancer" to be addressed.

(1) Distinction between specific and non-specific diseases and causal inference.

(2) Relative risk and attributable fraction of smoking for the cancer types involved.

(3) Application of epidemiological study results in a population to individual causation.

Along with these perspectives, the ad-hoc Committee wishes to make an additional point about the role of epidemiological studies in identifying disease causation.

\section{THE DICHOTOMY OF SPECIFICAND NON-SPECIFIC DISEASES IS DEVOID OF A SCIENTIFIC FOUNDATION}

Since the introduction of the concept of specific and non-specific diseases during the case of the "Vietnam veterans" class action lawsuit as "Agent Orange victims" (hereafter referred to as "Agent Orange Lawsuit"), the Supreme Court of the Republic of Korea has continued to use this concept in tobacco lawsuits and exhaust gas lawsuits. The brief of the tobacco companies has emphasized, "lung cancer is a non-specific disease."

In the Supreme Court ruling on the Agent Orange Lawsuit, a specific disease is defined as "a disease caused by a specific etiology in which pathogenic cause and effect are clearly traceable" and a non-specific disease as "a disease with complex etiologies and mechanisms that develops in complex interactions between genetic factors, such as heredity and predisposition, and non-genetic factors, such as alcohol drinking, smoking, age, dietary habits, and occupational and environmental factors" (Supreme Court Ruling 2014-04-10. Sentencing 2011C22092 Decision). The criteria for a specific disease pointed out in the Supreme Court Ruling of the Agent Orange Lawsuit are as follows: (1) "stemming from one etiology" and (2) a clear correspondence between pathological cause and effect.

Regarding this, the opinion of the ad-hoc Committee is as follows.

First, the terms "specific disease" and "non-specific disease" are not used in the epidemiologic field dealing with disease causation. These terms have no entries in the Dictionary of Epidemiology [1] edited by the International Epidemiologic Association; Modern Epidemiology [2], a textbook of epidemiology; or Gordis' Epidemiology [3]. Second, these terms are not familiar, even to epidemiologists. While specificity is mentioned as one of the considerations that may be considered in disease causation, dichotomizing diseases into specific and non-specific diseases is not acceptable in the epidemiological discipline that deals with disease causation.

Nevertheless, if a specific disease were to be defined as a dis- ease having necessary and sufficient conditions stemming from a single cause, such a specific disease cannot exist. Even in case of an infectious disease, while it is considered to develop owing to a specific bacterial or viral species as a direct cause, a number of other factors are also involved in disease occurrence. This also applies to tuberculosis and cholera, which are mentioned in the brief submitted by KT\&G (2015-01-15, p. 24) as examples of specific diseases. Mycobacterium tuberculosis (Mtb) is a necessary condition for tuberculosis (TB), because without Mtb, there would be no TB. However, although a high proportion of the Korean population are Mtb carriers, only a very low percentage of them are TB patients. In other words, Mtb is not a sufficient condition for TB in that TB occurs only under specific conditions, such as malnutrition, hygienic problems, immunodeficiency disorders, or use of immunosuppressant drugs. In addition, in the case of cholera, only some of those infected with Vibrio cholerae show the typical symptoms of cholera accompanied by acute watery diarrhea. Furthermore, most of the leading chronic diseases in Korea, including lung cancer, are not diseases with a single etiology. They occur by complex interactions between various risk factors through various mechanisms. Nonetheless, even though they are not considered "specific diseases," their causal connection to environmental risk factors cannot be denied. As an example, it is not correct to categorically deny the causal link between occupational radiation exposure and cancers among those occupationally engaged in radiological exposures and thus not recognize these cancers as occupational diseases simply because cancer does not meet the definition of a specific disease. The practice of dichotomizing diseases into specific and non-specific diseases in assessing the effects of risk factors is based on a false understanding of disease causation; it is therefore improper to use it as a basis for assessing the causal link in the Tobacco Lawsuit.

The "clear correspondence between cause and effect" presented as the second criterion for a specific disease is conceptually close to specificity, which is one of Hill's considerations for causation. For example, if risk factor A is not related to other diseases, but is related to disease B, a specificity can be determined to exist between risk factor $A$ and disease B. Additionally, if risk factor A has a low relative risk in relation to other diseases, but has a very high relative risk in relation to disease $\mathrm{B}$, a specificity can be determined to exist between risk factor A and disease B. Under this logic, the affected group in the Tobacco Lawsuit, i.e., patients with three types of lung cancer who have a smoking history of 20 pack-years or more and who have smoked for 30 years or more may be regarded as having a high level of "specificity" for lung cancer.

In sum, it is not acceptable to dichotomize a disease as being either specific or non-specific. Moreover, if specificity can be determined in terms of magnitude of the causal relationship be- 
tween a specific etiology (cause) and a disease (effect), the level of specificity between smoking and the cancer types involved in the current Tobacco Lawsuit can be said to be very high.

\section{THE ATTRIBUTABLE FRACTION OF SMOKINGTOTHE CANCERTYPES INVOLVED INTHETOBACCO LAWSUIT RANGES FROM 81.5\% TO 95.4\%}

Both the plaintiff and the defendants of the Tobacco Lawsuit have mentioned the relative risk and attributable fraction (also used as attributable risk) in the relationship between smoking and lung cancer. In particular, the tobacco companies emphasize that the data related to relative risk and attributable fraction in Korea are lower compared to foreign data. For example, in the brief submitted in January 2015 (Philip Morris Korea, 2015-01-14, Brief p. 9), based on the data reported in BMC Cancer in 2014 [4], Philip Morris Korea presents that "the population attributable fraction is $53.3 \%$ for cigarette smoking."

Various epidemiological data are presented in the ongoing Tobacco Lawsuit. The parties have presented the population attributable fraction, and the relative risk for lung cancer in the entire smokers; however, these data cannot be recognized as epidemiological indicators worth consideration in the current litigation. In this regard, the ad-hoc Committee presents the following views.

First, the affected group of this class action are patients with small cell lung cancer, squamous cell lung cancer, and squamous cell laryngeal cancer, who have a smoking history of 20 packyears or more and a smoking period of 30 years or more. Therefore, the scientific foundation for the arguments advanced in the Tobacco Lawsuit should be focused on the relative risk and attributable fraction of these affected individuals.

Second, the population attributable fraction mentioned in the Tobacco Lawsuit is an indicator that assesses the causal contribution of smoking in the entire population, including non-smokers. Given that the Tobacco Lawsuit involves only lung cancer patients with a smoking history, the population attributable fraction is not an adequate indicator for the Tobacco Lawsuit, and the arguments about the causal relationship between smoking and lung cancer should be based on the attributable fraction among the exposed group (smokers).

Third, the results of the studies conducted in Korea in relation to the cancer types included in the Tobacco Lawsuit are as follows. In a Korean study published in 2005 [5], the relative risks of smokers for the development of small cell lung cancer and squamous cell lung cancer with respect to non-smokers were estimated at 21.7-fold and 11.7-fold, respectively. According to a 2004 study on laryngeal cancer [6], the relative risk of smokers for the development of laryngeal cancer with respect to non- smokers was estimated at 5.4-fold. The attributable fractions of smokers calculated based on the relative risks $(=[R R-1] / R R)$ sof small cell lung cancer, squamous cell lung cancer, and laryngeal cancer (RR of 21.7-, 11.7-, and 5.4-fold, respectively) were $95.4 \%, 91.5 \%$, and $81.5 \%$, respectively. These results demonstrate much higher attributable fractions compared to the attributable fractions ( $53 \%$ to $70 \%$ ) calculated on the basis of the relative risks of smoking for overall lung cancer without cytohistological consideration (RR, 2.5 to 5.0 ).

In sum, in consideration of the cancer types involved in the Tobacco Lawsuit, the attributable fraction of the exposure group (smokers), not the population attributable fraction, is the appropriate indicator of the causal contribution of smoking to lung cancer. Based on the results of domestic research, the relative risks and attributable fractions for the cancer types involved in the Tobacco Lawsuit are much greater than those mentioned so far by defendants in the arguments advanced in the Tobacco Lawsuit.

\section{THE EPIDEMIOLOGICAL RESEARCH RESULTS SHOULD BE CONSIDEREDTHE MOST IMPORTANT FACTOR IN ASSESSING INDIVIDUAL CAUSAL CONNECTIONS BETWEEN SMOKING AND LUNG CANCER}

Tobacco companies have put forward arguments that information regarding the causal link between smoking and lung cancer is based on studies in populations (general causality) and cannot be used for assessing individual causal links (individual causality). Regarding this, the views of the ad-hoc Committee are as follows.

First, the medical society accepts the causal link between smoking and lung cancer as a scientifically proven fact. The rationale for this recognition stems from a variety of studies, not just follow-up studies with population groups. Cohort studies have played an important role in quantifying the extent of damages caused by smoking. On a related note, animal experiments, observation studies with individual patients, and chemical assays have greatly contributed to determining the mechanisms by which smoking induces lung cancer [7]. Such individual observations and experiments have yielded well-established factual findings, such as the occurrence of tumors when "tobacco juice" was smeared on animals' skin; smoking-induced pulmonary ciliostasis, in which smoking impeded the activity of the upper bronchial cilia and thus triggered the trapping of hazardous substances in the lungs; and evidence of the presence of carcinogenic substances such as benzopyrene in tobacco smoke. The body of knowledge about the causal link between smoking and lung cancer has thus been formed through population studies, animal experiments, observations of individual patients, and 
laboratory studies.

Second, the argument that epidemiological evidence cannot be used as information proving the individual causal relationships because they are "in principle, statistics on population groups" contains a serious argumentative gap. In modern clinical medicine, clinical trials with population groups are recognized as the best approach to assess the efficacy of a therapy. If statistics obtained from a population group cannot be applied to individual cases, the inevitable conclusion is that the body of knowledge established through a multitude of clinical trials should not be applied at all in clinical settings in diagnosing patients and selecting therapies. This is obviously an erroneous conclusion that stems from a faulty premise. The general causality verified in a population group is expressed as the sum total of individual causality of the members constituting that population group. Risk factors and causal relationships to a disease can be determined more accurately through epidemiological studies with the affected population group than through individual observations of the members of that group. Therefore, the approach using population groups is not a limitation of epidemiological study; rather, it is a strength that can overcome the limitations of assessing individual cases.

Third, the argument that epidemiological evidence cannot be used as information proving the individual causality because they are population-based statistics contains a serious error in logic. If epidemiological evidence cannot be applied to individuals and the statistical proofs obtained from population group do not have any explanatory power on individual cases, it would indicate that those who have ceased smoking on the basis of the epidemiological evidence have made an irrational decision. Furthermore, if the epidemiological evidence is not applicable among individuals, advice and therapies for tobacco cessation by many physicians in the clinical setting (e.g., "Quit Smoking Clinic") can also be labeled as useless activities. The claim that the statistical results obtained from population groups cannot be applied to individual cases is tantamount to accusing all those who quit and attempt to quit smoking and physicians who recommend smoking cessation of irrational decision-making, which is not socially and practically acceptable. That smoking is a causal factor for lung cancer is widely established general knowledge, which is also clearly described as a warning on cigarette packs. It is the responsibility of the field of preventive medicine to explore ways and means to prevent disease and promote the health of individuals by applying knowledge about etiologies and causal mechanisms of diseases. It is the duty of all and an important activity of those concerned to spread such knowledge, to warn youth against the dangers of smoking to prevent them from starting smoking, and to guide smokers toward cessation: all of this is based on applying the knowledge obtained from population groups to individuals.
Fourth, it is essential to use the concept of probability of causation in relation to the application of the attributable fractions verified in the data from population studies at the individual level. According to the Dictionary of Epidemiology, probability of causation for a given case is the probability that exposure played a role in disease occurrence [1]. This concept is considered important in establishing legal standards, because it concerns the probability for the case in which a randomly selected patient had developed a given disease from exposure to the factor being investigated [2]. The concept of probability of causation is an important concept presented in epidemiology textbooks. However, it has not been reflected so far in the Tobacco Lawsuit and prior tobacco lawsuits in Korea. Instead, a problematic and erroneous claim has been put forward that the attributable fractions derived from studies with population groups cannot be applied to individual cases, thus revealing a serious problem. The concept of probability of causation is intuitively applied in practical decision-making. For example, an individual who has smoked for 10 years is diagnosed with lung cancer, and his/her physician says that it cannot be verified whether the lung cancer was triggered by smoking because populationbased knowledge cannot be applied to an individual, thus implying that smoking can be continued. In this scenario, the physician has certainly failed to do his/her duty as an expert who must consider scientific evidence in a balanced way and make the best possible rational recommendations. In reality, the probability that smoking caused the lung cancer of this patient is very high, and continuing smoking will assuredly exacerbate the course of the disease, which is also understood based on the probability of causation.

Fifth, the information on attributable fractions obtained from epidemiological studies with population groups needs to be considered in the court to assess the probability of causation of lung cancer in the individual patients. The presence of a particular relationship between attributable fractions and the probability of causation has been proven, with the probability of causation being equal to or greater than the attributable fraction $[1,2]$. In other words, even in a case where the attributable fraction is low, the probability of causation can be very high. For example, the Dictionary of Epidemiology demonstrates that a case with an attributable fraction of $20 \%$ can exhibit a probability of causation of $100 \%$ [1]. Because probability of causation can be accurately estimated on the basis of a biological mechanism, even in a case where the attributable fraction is very low, its probability of causation can be $100 \%$ in the presence of an obvious biological mechanism [8]. In the case of the affected group in the Tobacco Lawsuit, i.e., patients with small cell lung cancer, squamous cell lung cancer, or squamous cell laryngeal cancer who have a smoking history of 20 pack-years or more and have smoked for 30 years or more, they have at- 
tributable fractions ranging from $80 \%$ to $90 \%$ or more. Consequently, if the general causality between smoking and lung cancer is recognized, and the individual patient can be considered to have randomly been selected from the lung cancer patients, the probability of causation of smoking being the cause of the lung cancer of this patient is $80 \%$ to $90 \%$ or more. It is necessary to assess the probability of causation of individual lung cancer patients using these considerations. Using the concept of probability of causation, a recent study estimated that over $90 \%$ of the lung cancer cases in Quebec, Canada are legally attributable to smoking [9].

In sum, the claim that the statistically established causal relationship in population cannot be applied to individual cases is logically and practically problematic. The information on the causal link between smoking and lung cancer can be applied to individual cases with the concept of probability of causation.

\section{THE ROLE OF EPIDEMIOLOGY INASSESSING CAUSALITY}

In the course of the Tobacco Lawsuit, many different arguments have been put forward regarding the role of epidemiology in determining the causality of a disease. Some of the arguments are not admissible from the viewpoint of experts in the field of epidemiology. The discipline of epidemiology is the academic foundation of the Korean Society for Preventive Medicine and the Korean Society of Epidemiology. As such, it is judged to be of vital importance to provide a correct understanding and increase awareness of the role of epidemiology to the press and general public watching the Tobacco Lawsuit.

The ad-hoc Committee wishes to express deep concerns about the following contents described in the briefs submitted by the parties concerned.

"Epidemiology is a discipline investigating population groups and thus cannot be used as a tool for determining the etiology of the given disease in individual cases. Therefore, even though an epidemiological study quantitatively detected a cause-effect relationship in a particular group, a conclusion drawn does not provide a suitable basis for the application to the individuals belonging to that group. This may be pointed out as an inherent limitation of epidemiology itself" (KT\&G, 2015-01-15, brief p. 10).

"Epidemiology is a discipline investigating the correlation between particular factors and a given disease, and the results of epidemiological studies are, in principle, statistics limited to the population group being investigated" (BAT Korea, 2014-12-26, brief p. 12).

In particular, KT\&G (brief 2015-01-15) assigned a separate chapter titled "Limitations of Epidemiology" describing the limitations of epidemiology in relation to the arguments made in the course of the Tobacco Lawsuit.

In deriving the causality of a given disease, epidemiology reflects not only the research data derived from the studies with the corresponding population group, but also from animal experiments, observations of individual patients, and laboratory studies, comprehensively considering their contributions. Epidemiology derives the attributable fraction, which means the causal contribution of a particular risk factor to the incidence of the given disease, from the data of population group studies. Additionally, using the concept of probability of causation, it also provides information on the causal contribution to the disease in individual cases. Determining the conclusions drawn from epidemiological studies as statistics that "cannot be applied to individuals" or making claims on the "limitations of epidemiology" is depreciating the broad intellectual activities of epidemiologists to elucidate the causalities of diseases and denying the essential tasks of the preventive medicine.

It is suspected that the reason underlying such irrational claims criticizing the "limitations of epidemiology" and determining the results of epidemiological studies as mere "statistical relations," is the intent to prevent the results of epidemiological studies regarding the causal link between smoking and lung cancer from being taken as proof of causality in the court. The ad-hoc Committee regards such arguments as an important social issue that can seriously harm efforts of the whole society to prevent diseases and promote health that goes beyond the interest of particular groups.

\section{CONCLUSION}

In relation to the ongoing Tobacco Lawsuit, the Korean Society for Preventive Medicine and the Korean Society of Epidemiology constituted an ad-hoc Committee of the Korean Society for Preventive Medicine and the Korean Society of Epidemiology on Tobacco Lawsuits and presented the results of the joint ad-hoc Committee's discussions in the form of a joint statement as a position paper declaring their opinions. The decision and ensuing activity of the two societies arose from the ongoing debates about the causal link between tobacco smoking and lung cancer in the course of the Tobacco Lawsuit, thereby regarding it as the social duty of the two societies as experts in the disease causation to clarify their positions and publicize their opinions based on the latest scientific discussions. It was of particular importance to bring out the value of epidemiology as a discipline, given the related negative arguments put forward by the parties concerned in relation to the causality of the diseases involved in the Tobacco Lawsuit. It is hoped that this joint statement of the ad-hoc Committee will assist in initiating more clear and scientific debates in the course of the Tobacco Lawsuit. 


\section{Ad-hoc COMMITTEE OFTHE KOREAN SOCIETY FOR PREVENTIVE MEDICINE ANDTHE KOREAN SOCIETY OF EPIDEMIOLOGY ONTOBACCO LAWSUITS}

Member List (in Korean alphabetical order after the Joint Chairs)

Cho, Sung-Il

Joint Chair, Professor, Graduate School of Public Health, Seoul National University Director of the Institute of Public Health and Environment, Seoul National University Editor-in-Chief of the Journal of Preventive Medicine and Public Health [scho@ snu.ac.kr, +82-2-880-2717]

Kim, Dong-Hyun Joint Chair, Professor, Hallym University College of Medicine

Chair of the Social Health Committee, Korean Society for Preventive Medicine

Khang, Young-Ho Professor, Seoul National University College of Medicine

International Journal of Epidemiology, Editor Director of the Institute of Health Policy and Management, Seoul National University Medical Research Center

Park, Soon-Woo Professor, Catholic University of Daegu School of Medicine

President of the Korean Society of School Health

Park, Eun-Cheol Professor, Yonsei University College of Medicine

Director of the Institute of Health Services Research, Yonsei University

Park, Hyung-Wook Direcor of Legislation, Korean Academy of Medical Sciences

Shin, Min-Ho

Associate Professor, Chonnam National University Medical School

Shin, Aesun

Lee, Kang-Sook Associate Professor, Seoul National University College of Medicine

Professor, The Catholic University of Korea College of Medicine

Lee, Sun Goo

Assistant Professor, Gachon University School of Medicine

Cheong, Hae-Kwan Professor, Sungkyunkwan University School of Medicine

Vice-chair of the Korean Society of Epidemiology

Cho, Hong-Jun $\quad$ Professor, University of Ulsan College of Medicine

Chair of the Korea Society for Research on Nicotine and Tobacco
Jee, Sun-Ha

Professor, Graduate School of Public Health, Yonsei University

Director of the Institute for Health Promotion, Yonsei University

Regular Member of the National Academy of Medicine of Korea

Hwhang, Seung-Sik Associate Professor, Graduate School of Medicine, Inha University

Director of the Prevention Center, Incheon Cardiovascular Disease Center

\section{CONFLICT OF INTEREST}

The authors have no conflicts of interest to declare for this study.

\section{SUPPLEMENTARY MATERIAL}

Supplementary material is available at http://www.e-epih.org/.

\section{REFERENCES}

1. Porta MS, Greenland S, Hernán M, Santos Silva ID, Last JM; International Epidemiological Association. A dictionary of epidemiology. 6th ed. Oxford: Oxford University Press; 2014, p. 1-343.

2. Rothman JK, Greenland S, Lash TL. Modern epidemiology. 3rd ed. Philadelphia: Lippincott Williams \& Wilkins; 2008, p. 1-758.

3. Gordis L. Epidemiology. 5th ed. Philadelphia: Elsevier/Saunders; 2013, p. 1-392.

4. Park S, Jee SH, Shin HR, Park EH, Shin A, Jung KW, et al. Attributable fraction of tobacco smoking on cancer using population-based nationwide cancer incidence and mortality data in Korea. BMC Cancer 2014;14:406.

5. Yun YH, Lim MK, Jung KW, Bae JM, Park SM, Shin SA, et al. Relative and absolute risks of cigarette smoking on major histologic types of lung cancer in Korean men. Cancer Epidemiol Biomarkers Prev 2005;14(9):2125-2130.

6. Jee SH, Samet JM, Ohrr H, Kim JH, Kim IS. Smoking and cancer risk in Korean men and women. Cancer Causes Control 2004;15(4): 341-348.

7. Proctor RN. The history of the discovery of the cigarette-lung cancer link: evidentiary traditions, corporate denial, global toll. Tob Control 2012;21(2):87-91.

8. Beyea J, Greenland S. The importance of specifying the underlying biologic model in estimating the probability of causation. Health Phys 1999;76(3):269-274.

9. Siemiatycki J, Karp I, Sylvestre MP, Pintos J. Estimating the proportion of cases of lung cancer legally attributable to smoking: a novel approach for class actions against the tobacco industry. Am J Public Health 2014;104(8):e60-e66. 


\section{흡연과 폐암의 인과성에 대한 〈대한예방의학회 - 한국역학회 담배와 폐암 소송 관련 특별위원회>의 의견}

대한예방의학회 · 한국역학회 담배와 폐암 소송 관련 특별위원회

\section{1. 경과와 배경}

국민건강보험공단이 담배회사인 (주)KT\&G, (주)필립모리스코 리아, (주)BAT코리아를 상대로 한 흡연 피해 손해배상청구 소송 (이하 담배소송)이 진행중이다. 이 과정에서 흡연과 폐암 간의 인 과성 논쟁이 이루어지고 있다. 이번 소송 대상은 3 개 암종(소세포 폐암, 편평상피세포 폐암, 편평상피세포 후두암)의 하나가 발생한 환자 중에서 흡연력이 20갑년(packyears) 이상이고 흡연기간이 30 년 이상인 환자이다.

흡연은 국민건강을 위협하는 매우 중요한 위험요인이므로, 질병 예방과 건강증진을 학회의 핵심적 가치로 삼고 있는 「대한예방의 학회」(이사장 이원철)와「한국역학회」(회장 최보율)에서는 담배 소송, 특히 그 과정에서 일어나는 흡연과 폐암의 인과성 논쟁에 관 심을 두어 왔다.

원고측(국민건강보험공단측)과 피고측(담배회사측)이 법원에 제출한 준비서면에서 환경적 유해요인인 담배와 폐암과의 인과적 관련성 판정에서 역학연구(epidemiologic study)의 가치와 역할이 반복적으로 거론되고 있는 상황에서 역학을 핵심 학문분야로 삼고 있는 「대한예방의학회」와「한국역학회」는 해당 문제에 대한 깊은 우려와 함께 의견 표명의 필요성을 절감하게 되었다.

이에「대한예방의학회」와「한국역학회」는 공동으로 <대한예방 의학회.한국역학회 담배와 폐암 소송 관련 특별위원회>(이하 특 별위원회)를 구성하기로 합의하였고, 관련 분야 전문가로 특별위 원회를 구성하였다(특별위원회에 참여한 위원 명단은 첨부 자료 참조).

특별위원회는 그간 두 차례의 세미나, 이메일을 통한 논의, 의견 서 초안에 대한 의견수렴과 수정과정을 거쳐 의견서를 작성하였 고, 「대한예방의학회」와「한국역학회」이사진의 동의 절차를 거 쳐 양 학회의 이름으로 이 의견서를 발표하게 되었다.

\section{2. '흡연과 폐암 발병 간의 인과관계'에 대한 쟁점}

상기한 담배소송에서는 질병의 인과성에 대한 역학의 역할에 대 하여 논란이 이루어지고 있으며, 준비서면의 기술 내용 중에는 역 학 연구의 가치와 역할에 대한 잘못된 인식을 바탕으로 만들어진 것들이 있다. 역학은「대한예방의학회」와「한국역학회」의 학문적 기반을 구성하기 때문에, 질병의 인과성에 대한 역학의 역할에 대 하여 올바른 인식을 제공하는 것은 양 학회와 특별위원회의 학문 적, 사회적 책무라고 판단하고 있다.

따라서 특별위원회는 담배소송의 원고측(국민건강보험공단측) 과 피고측(담배회사측)이 법원에 제출한 준비서면에 대한 검토를 통하여, '흡연과 폐암 발병 간의 인과관계'와 관련한 다음의 세 가 지 쟁점을 다루었다.

(1) 특이성 질환과 비특이성 질환의 구별과 인과관계 추론의 문제
(2) 소송 대상 암종에 대한 흡연의 상대위험도와 기여위험분율

(3) 인구집단을 대상으로 한 역학연구 결과를 개인에서의 인과 관계에 적용하는 문제

이들과 함께 특별위원회에서는 질병의 인과성 규명에 있어 역학 연구의 역할에 대하여 추가적인 입장을 표명하고자 한다.

\section{3. 특이성 질환과 비특이성 질환의 이분법적 구분은 학문적 근거가 없다.}

우리나라 대법원에서는 '베트남전 참전군인 고엽제 피해 손해배 상청구 소송'(이하 고엽제 소송)에서 특이성 질환과 비특이성 질환 이라는 개념을 도입한 이래, 담배소송 사건과 자동차배출가스로 인한 손해배상청구 사건 등에서 계속 이 개념을 사용하고 있다. 담 배회사측의 준비서면에서도 '폐암은 비특이성 질환'이라는 점을 강조하고 있다.

고엽제 소송의 대법원 판결 원문에서는 특이성 질환은 “특정 병 인에 의하여 발생하고 원인과 결과가 명확히 대응하는" 질환이며, 비특이성 질환은 “그 발생 원인 및 기전이 복잡다기하고, 유전·체 질 등의 선천적 요인, 음주, 흡연, 연령, 식생활습관, 직업적.환경적 요인 등 후천적 요인이 복합적으로 작용하여 발생하는 질환”으로 정의하고 있다(대법원 2014. 4. 10. 선고 2011다22092 판결). 고엽 제 소송에서 대법원 판결문이 밝히는 특이성 질환의 조건은 (1) '하 나의 병인에 의하여 발생’하여야 하고, (2) 병인(원인)과 질병 발병 (결과)이 명확하게 대응하여야 한다. 이에 대한 특별위원회의 의견 은 다음과 같다.

첫째, 특이성 질환(specific disease), 비특이성 질환(non-specific disease)이라는 용어는 질병의 인과성을 다루는 역학 분야에서 사 용되지 않는 용어이다. 국제역학회 (International Epidemiologic Association)가 발간한 역학사전[1]이나 역학 분야의 교과서라고 할 수 있는 현대 역학(Modern Epidemiology) [2], Gordis의 역학 (Epidemiology) [3] 책자에서도 특이성 질환, 비특이성 질환이라는 표현은 등장하지 않는다. 둘째, 이들 용어는 역학자들에게도 생소 한 용어이다. 특이성(specificity)이 질병의 인과성에 대한 고려사항 중의 하나로 언급되지만, 질병을 특이성 질환, 비특이성 질환으로 구분하는 것은 질병의 인과성을 다루는 역학 분야에서 받아들여지 지 않는다.

하지만 특이성 질환을 단일 원인에 의한 필요충분조건을 가지는 질환으로 정의하고자 한다면, 이와 같은 특이성 질환은 존재할 수 없다. 감염성 질환의 경우에도 감염을 일으키는 세균, 바이러스 때 문에 발생하는 것으로 여기지만, 실제 질병 발병에는 수많은 다른 요인들이 관여한다. 담배회사측이 준비서면(KT\&G측 2015. 1. 15. 준비서면 24페이지)에서 특이성 질환의 사례로 언급하고 있는 결 핵, 콜레라 등도 그러하다. 결핵균이 있어야 결핵환자가 되기에 이 는 결핵 발병의 필요조건이긴 하지만, 우리나라 국민의 상당수가 
몸속에 결핵균을 지니고 있음에도 불구하고 결핵환자는 전체 인구 중 소수이며, 특정 조건(예를 들어 영양결핍 상태, 위생상태의 문제, 면역결핍성 질환 또는 면역억제제 사용 상태 등)이 갖추어질 때에 만 결핵이 발생한다는 점에서 결핵균 감염은 결핵 발병의 충분조 건이 될 수 없는 것이다. 콜레라도 콜레라균의 감염된 사람 중 심한 물 설사를 동반하는 전형적 콜레라 증상을 보이는 경우는 일부에 지나지 않는다. 더구나 폐암을 포함해 현재 우리나라에서 흔히 발 생하는 대부분의 만성질환은 단일 원인에 의한 질환이 아니다. 다 양한 경로로 다양한 위험요인들의 복합적 작용으로 질병이 발생하 게 된다. 즉 소위 '특이성 질환'이 아니라고 해서 이들 질환과 환경 적 유해요인들과의 인과적 관련성을 부정할 수는 없는 것이다. 대 표적인 예로서, 방사선작업 종사자에게서 발생한 암의 업무상 질병 인정 절차에 있어서, 암이 특이성 질환이 아니라는 이유로 인과적 관련성을 근원적으로 부정하는 것은 잘못이다. 질병을 특이성 질 환과 비특이성 질환으로 나누어 유해요인의 영향을 평가하는 관행 은 질병에 대한 잘못된 이해에 근거하고 있기 때문에, 담배소송의 핵심쟁점인 인과성을 평가하는 근거로 사용하는 것은 부적절하다.

특이성 질환의 두 번째 조건으로 제시된 '병인(원인)과 질병 발 병(결과)이 명확하게 대응'한다는 점은 Hill의 인과성 고려사항 (Hill's considerations for causation) 중에 특이성에 가깝다고 할 수 있다. 예를 들어, $\mathrm{A}$ 라는 위험요인이 다른 질환들과는 관련성이 없 는데 $\mathrm{B}$ 라는 질환과는 관련성이 나타났을 경우, $\mathrm{A}-\mathrm{B}$ 간에는 특이성 이 있다고 판단할 수 있다. 또한 $\mathrm{A}$ 라는 위험요인과 다른 질환들과 는 상대위험도가 그리 크지 않은데, B 질병과는 상대위험도가 매우 크다면 $\mathrm{A}$ 라는 병인과 $\mathrm{B}$ 라는 질병 간에는 특이성이 있다고 할 수 있 다. 이 점에서 이번 담배소송의 대상군, 즉, 소세포 폐암, 편평상피 세포 폐암, 편평상피세포 후두암, 그리고 흡연력이 20갑년 이상이 면서 흡연기간이 30 년 이상인 환자의 경우 이와 같은 ‘특이성'이 매 우 높다고 할 수 있다.

요약하면, 어떤 질환을 특이성 질환과 비특이성 질환으로 이분 법적으로 구분하는 것은 받아들여질 수 없다. 만약 특정 병인(원 인)과 질병 발생(결과)의 관련성의 측면에서 특이성이 정의될 경 우, 흡연과 현재의 담배소송 대상 암종 간에는 특이성이 매우 높다 고 할 수 있다.

\section{4. 담배소송 대상 암종에서 흡연의 폐암 발생 기여 위험분율은 $81.5 \%-95.4 \%$ 정도이다.}

담배소송에서 흡연과 폐암의 관련성에 대한 상대위험도(relative risk)와 기여위험분율(또는 기여위험도라고도 부른다, attributable fraction)이 원고측과 피고측에 의해 제시되고 있다. 특히 담배회사 측은 우리나라 자료에서의 상대위험도와 기여위험분율이 외국 자 료에 비해 낮다는 점을 강조하고 있다. 예를 들어 2015년 1월 담배회 사측이 제출한 준비서면(필립모리스측 2015. 1. 14. 준비서면 9페이 지)에서는 2014년도 BMC Cancer지에 보고된 자료[4]를 근거로 '흡연의 폐암 발병에 대한 일반인구 기여위험도는 $53.3 \%$ '라는 점 을 제시하고 있다.

현재 진행중인 담배소송에서는 다양한 역학 자료가 제시되고 있 다. 전체 폐암 환자에 대한 상대위험도와 노출군에서의 기여위험 분율, 전체 인구집단에서의 기여위험분율, 전체 흡연자에서의 폐 암 발생에 대한 상대위험도 등이 제시되고 있으나, 이들은 본 소송 에서 직접적으로 다루어야 할 역학 지표라고 할 수 없다. 이와 관련 하여 특별위원회는 다음과 같은 의견을 제시한다.

첫째, 이번 소송의 대상자는 그간 흡연과의 인과적 관련성의 크 기가 큰 것으로 보고된 소세포 폐암과 편평상피세포 폐암, 후두암 중 편평상피세포암 환자이며, 흡연력이 20갑년(packyears) 이상이
면서 흡연기간이 30 년 이상인 환자를 대상으로 한다. 그러므로 담 배소송에서 다루어지는 과학적 근거는 이들 대상자에서의 상대위 험도와 기여위험분율에 초점이 맞춰져야 한다.

둘째, 담배소송에서는 인구집단 기여위험분율(population attributable fraction)이 언급되고 있는데, 이는 비흡연자를 포함한 전체 폐암 환자 중에서 흡연의 인과적 기여도를 평가하는 지표이 다. 그러나 이번 담배소송에서는 흡연력을 지닌 폐암 환자를 대상 으로 하므로 인구집단 기여위험분율은 담배소송의 적절한 지표라 고 할 수 없으며, 담배소송에서 인과성에 대한 논의는 흡연자에서 의 기여위험분율을 토대로 이루어져야 한다.

셋째, 담배소송 대상 암종을 고려하여 우리나라의 연구 결과를 보면 다음과 같다. 2005년 발표된 국내연구에 의하면[5], 비흡연자 대비 현재흡연자의 소세포 폐암 발생의 상대위험도는 21.7 배, 편평 상피세포 폐암 발생의 상대위험도는 11.7 배이었다. 후두암의 경우 2004년 연구에 의하면[6], 비흡연자 대비 흡연자는 후두암 상대위 험도가 5.4배이었다. 소세포 폐암, 편평상피세포 폐암, 그리고 후두 암에 대한 흡연의 상대위험도 21.7배, 11.7 배, 5.4배를 이용하여 계산 한 흡연자의 '폐암' 발생 기여위험분율[=(RR-1)/RR]은 각각 $95.4 \%$, $91.5 \%$, 그리고 $81.5 \%$ 이다. 이상의 결과는 그 동안 폐암을 세포조직 학적 분류로 나누지 않고 전체 폐암으로 연구 보고한 경우에 보고 된, 흡연의 상대위험도 범위 2.5 에서 5.0 , 그리고 기여위험분율의 범위 $53 \%$ 에서 $70 \%$ 와 비교하여 훨씬 높은 수치라고 할 수 있다.

요약하면, 소송 대상 암종과 흡연력을 고려할 때, 흡연-폐암의 인과적 기여도에 대한 지표로 인구집단 기여위험분율이 아닌 노출 군(흡연자)에서의 기여위험분율이 사용되어야 한다. 국내 연구결 과를 토대로 할 때 소송대상 암종에 대한 흡연의 상대위험도와 기 여위험분율은 그간 담배소송에서 논의되었던 수치들보다 매우 높 다고 할 수 있다.

\section{5. 역학연구 결과는 개인에서의 흡연-폐암의 인과관 계 를 평가하는데 있어서 가장 중요한 요소로 고려 되어야 한다.}

흡연과 폐암의 인과성에 대한 정보는 인구집단을 대상으로 한 연구에서 얻어진 것(일반적 인과성으로도 부름)으로서 이를 개인 에서의 인과성(구체적 또는 개별적 인과성으로도 부름)에 대한 정 보로 활용할 수 없다는 주장이 담배회사측에 의해 이루어지고 있 다. 이와 관련하여 특별위원회는 다음과 같은 의견을 제시한다.

첫째, 의학계에서는 흡연과 폐암의 인과성은 확립된 과학적 사 실로 받아들인다. 이의 배경에는 인구집단을 대상으로 한 추적 연 구 결과만을 근거로 한 것이 아니다. 코호트 연구가 흡연의 피해 정 도를 정량화하는 데에 많은 역할을 하였다. 한편 흡연이 폐암을 일 으키는 기전에 대해서는 흡연과 폐암의 인과성에 대한 근거 형성 에는 동물 실험, 개인 환자에서의 관찰, 화학물질 실험과 연구가 중 요한 기여를 하였다[7]. '담배 주스(tobacco juice)'를 동물에 발랐 을 때 종양이 발현하는 현상, 흡연이 상부기관지의 섬모 활동에 문 제를 일으켜 위해물질이 폐에 갇히게 되는 현상(섬모정체, ciliastasis), 담배 연기 속에 벤조피렌 등과 같은 발암물질이 존재한다는 사 실은 모두 개별적 관찰과 실험을 통해 밝힌 것이다. 흡연과 폐암의 인과성에 대한 정보는 이와 같은 인구집단 대상 연구, 동물실험, 개 인 환자에서의 관찰 결과, 실험실적 연구로부터 형성되었다.

둘째, 역학적 증거가 '본질적으로 인구집단을 대상으로 한 통계' 이므로 개별적 인과관계를 입증하기 위한 정보로 활용될 수 없다 는 주장은 논리적으로 분명한 문제를 지닌다. 현대 임상의학에서 질병치료 방법의 효능은 인구집단을 대상으로 하는 임상시험을 통 하여 평가하는 것을 최선으로 본다. 만약 인구집단을 대상으로 한 
통계를 개별 사례에 적용할 수 없다면, 수많은 임상시험으로 확립 된 지식을 일체 적용하지 않고 환자의 경과를 판단하고 치료방법 을 선택하여야 한다는 결론에 이른다. 이는 명백히 잘못된 결론으 로서, 잘못된 전제로부터 나오는 것이다. 인구집단에서 관찰된 일 반적 인과성은 그 집단을 구성한 개개인에서 나타나는 개별적 인 과성의 총합으로 나타나는 것이다. 오히려, 대부분의 기여요인과 질병의 인과적 관련성은 개개인만 관찰하기보다 인구집단을 대상 으로 한 역학연구를 통해서 정확하게 파악되기도 한다. 따라서, 인 구집단을 대상으로 하는 접근은 역학연구의 한계가 아니라, 반대 로 개별 사례 판단의 한계를 극복하기 위한 역학연구의 강점이라 고 할 수 있다.

셋째, 역학적 증거가 인구집단 통계이므로 개인에게는 활용할 수 없다는 주장은 실천적으로도 큰 문제를 지닌다. 역학적 증거를 개인에게 적용할 수 없고 인구집단 대상의 통계적 증거가 개인에 대해서는 아무런 이야기를 할 수 없다면, 역학 연구가 제시하는 증 거를 토대로 폐암을 회피하기 위해 흡연을 중단한 흡연자는 매우 불합리한 판단을 한 셈이 된다. 또한 진료실에서 이루어지는 수많 은 의사들에 의한 금연 권고 활동(금연클리닉 운영 등) 또한 “쓸모 없는 활동'으로 규정될 수 있다. 인구집단의 통계적 결과를 개인에 적용할 수 없다는 주장은 수많은 금연 시도자와 진료 의사들을 불 합리한 의사 결정자로 내모는 것이며, 이러한 주장은 사회적으로 나 실천적으로 받아들여질 수 없다고 판단한다. 흡연이 폐암을 일 으키는 원인이라는 것은 이미 확립된 일반적 지식이며, 이는 담뱃 갑 포장에도 경고문구로 명시되어 있다. 이와 같은 질병의 원인에 대한 지식을 적용하여 궁극적으로 모든 개인들의 질병예방과 건강 증진을 모색하는 것은 예방의학의 고유한 전문적 소임 중의 하나 이다. 누구나 이러한 지식을 가지도록 알리고, 청소년들이 흡연을 시작하지 않도록 예방하며, 흡연자들이 금연하도록 유도하는 것은 모두 중요한 활동으로서, 이 모두가 인구집단에서 얻은 지식을 개 인에게 적용하는 것이다.

넷째, 인구집단 자료에서 나타난 기여위험분율을 개인 수준에서 적용하는 문제와 관련하여 인과확률(probability of causation) 개념 이 활용될 필요가 있다. 역학사전에 따르면, 인과확률이란 특정 질 환자에서 노출 요인이 질병 발생에 관여하였을 확률(for a given case, the probability that exposure played a role in disease occurrence)을 의미하며[1], 무작위로 뽑힌 특정 질환자에서 질병이 노 출 요인에 의해 발생하였을 확률을 다루기 때문에 법적 기준을 정 하는 데에 중요하게 활용되어 왔다[2]. 인과확률 개념은 역학 교과 서에서 소개되어 온 주요 개념이나, 이전까지의 우리나라의 담배 소송 과정에서 다루어지지 않은 채, 인구집단 자료에서 도출된 기 여위험분율을 개인에게 적용할 수 없다는 주장만 이루어진 점은 문제라고 볼 수 있다. 인과확률 개념은 이미 실천적인 판단에 흔히 직관적으로 이용되고 있다. 예를 들어, 10 년간 흡연을 하였던 한 사 람이 폐암 진단을 받았다고 할 때, 만약 담당 의사가 말하기를 이 환자의 폐암이 흡연 때문인지 알 수 없고, 나아가 집단에 적용하는 지식을 개인에게 적용할 수 없으므로 계속 흡연을 하여도 좋다고 한다면, 이는 분명 과학적 증거를 균형 있게 고려할 전문가로서의 책임뿐만 아니라 최선의 합당한 권고를 할 윤리적 책임을 다하지 못하는 것으로 볼 수 있다. 이 흡연자의 폐암은 흡연에 기인했을 인 과확률이 높을 뿐더러, 계속되는 흡연은 앞으로 병세를 악화시키 는 원인이 될 인과확률이 높기 때문이다.

다섯째, 인구집단을 대상으로 역학 연구의 결과로 얻어진 기여 위험분율 정보로부터 개별 폐암 환자에서의 인과확률에 대한 판단 이 향후 법정에서 이루어질 필요가 있다. 학문적으로 기여위험분 율과 인과확률 간에는 일정한 관계가 존재하는 것이 증명되어 있 는데, 인과확률은 기여위험분율보다 같거나 크다 $[1,2]$. 즉, 기여위 험분율이 매우 낮더라도 인과확률은 매우 높을 수 있다. 예를 들어 역학사전에서는 기여위험분율이 $20 \%$ 이더라도 인과확률은 $100 \%$
일 수 있음을 보여주고 있다 [1]. 인과확률은 생물학적 기전에 근거 하여 보다 정확히 추정될 수 있으며, 기여위험분율이 매우 낮은 경 우에라도 분명한 생물학적 기전이 있다면 개별 사례의 인과확률은 $100 \%$ 일 수도 있는 것이다 [8]. 이번 담배소송의 대상군인 소세포 폐암, 편평상피세포 폐암, 편평상피세포 후두암, 그리고 흡연력이 20 갑년 이상이고 흡연기간이 30 년 이상인 환자의 경우, 기존 국내 연구를 토대로 할 때 기여위험분율이 $80 \%-90 \%$ 이상이다. 따라서 흡연과 폐암의 일반적 인과성이 인정되고 개별 환자가 위의 조건 을 가진 폐암 환자들 중에서 무작위로 뽑힌 것으로 본다면, 해당 개 별 환자에서 흡연이 폐암의 원인일 인과확률은 최소한 $80 \%-90 \%$ 이 거나 그 이상이 된다. 이러한 점에 기초하여 개별 폐암 환자에서의 인과확률에 대한 판단이 이루어질 필요가 있다. 최근의 한 연구에 서는 인과확률 개념을 이용하여 캐나다 퀘벡주의 폐암환자 중 $90 \%$ 이상이 법적으로 흡연의 기여에 의한 것(legally attributable to smoking)이라고 추정하였다 [9].

요약하면, 인구집단에서의 통계적 관련성을 개인에게 적용할 수 없다는 주장은 논리적, 실천적으로 문제를 지닐 수 있다. 인구집단 을 대상으로 얻어진 흡연과 폐암의 인과적 관련성에 대한 정보는 인과확률의 형태로 개인에서 활용될 수 있다.

\section{6. 인과성 판단에 있어서의 역학의 역할에 대한 입장}

담배소송 과정에서 질병의 인과성에 대한 역학의 역할에 대하여 여러 가지 주장들이 등장하였으며, 일부의 주장은 역학을 전공하 는 전문가의 입장에서 받아들일 수 없는 것들이 있다. 역학이라는 학문 분야는 「대한예방의학회」와「한국역학회」의 학술적 존재 기 반이므로, 담배소송을 바라보고 있는 언론과 일반 국민에게 역학 의 역할에 대한 올바른 인식을 제공하는 것이 매우 중요하다고 판 단한다.

특별위원회는 담배소송 준비서면에 등장하는 다음과 같은 기술 내용에 대해 깊은 우려를 가질 수밖에 없다.

"역학은 인간집단을 대상으로 하는 학문으로서 개별 환자에 대 해서는 그 질병발생 원인을 규명하기 위한 수단이 될 수 없습니다. 따라서 가령 역학연구에 의해 어떤 집단에서 원인-결과의 관계가 정량적으로 검출되었다고 해도 그 결론이 당해 집단에 속한 개인 에게 적합하다는 근거가 될 수는 없는 것입니다. 이 점은 역학 자체 에 내재하는 필연적 한계라 할 수 있습니다"(KT\&G측 2015. 1. 15. 준비서면 10페이지)

"역학은 인구집단을 대상으로 하여 특정 요인과 질병 사이의 상 관관계를 연구하는 학문으로서, 역학연구결과는 이와 같이 본질적 으로 인구집단을 대상으로 한 통계입니다" (BAT 코리아측 2014. 12. 26. 준비서면 12 페이지)

특히 KT\&G측의 준비서면(2015. 1. 15.)에서는 “역학의 한계”라 는 별도의 챕터(chapter)를 설정하고, 여기에 담배소송의 쟁점들에 대한 역학의 한계를 서술하고 있다.

역학은 질병의 인과성을 도출함에 있어 인구집단에서의 연구자 료 뿐만 아니라 동물실험, 개별 환자에서의 관찰결과, 실험실적 연 구 결과 등을 종합적으로 고려한다. 역학에서는 위험요인이 질병 발생에 대한 인과적 기여도를 의미하는 기여위험분율을 인구집단 자료를 통하여 산출하지만, 또한 인과확률이라는 개념을 통하여 개별 환자에서의 인과적 기여도에 대한 정보도 제공한다. 역학적 연구로 얻은 결론을 단순히 '개인에게 적용할 수 없는 통계'라고 규 정하거나 ‘역학의 한계’를 주장하는 것은 질병의 인과성을 규명하 기 위한 역학 연구자들의 광범한 지적 활동을 폄하하는 것이며, 아 울러 예방의학의 본질적인 임무를 부정하는 것이다.

이와 같이 '역학의 한계'를 논하고 역학 연구 결과를 '통계적 연 관성'으로만 규정하는 것은, 흡연-폐암에 대한 역학 연구 결과를 
인과성의 증거로 채택하지 못하도록 하려는 의도가 숨어 있는 것 으로 보며, 일부 집단의 이해관계를 넘어서 우리 사회 모든 사람의 질병예방과 건강증진을 위한 노력에 심각한 손실을 가져올 수 있 는 중대한 문제라고 특별위원회는 판단하고 있다.

\section{7. 맺음말}

현재 진행중인 담배소송과 관련하여 대한예방의학회와 한국역 학회는 <대한예방의학회.한국역학회 담배와 폐암 소송 관련 특별 위원회>를 구성하였고 논의 결과를 의견서의 형태로 제시하게 되 었다. 양 학회의 이와 같은 결정과 활동은 담배소송에서 흡연과 폐 암의 인과성에 대한 논의가 이루어지고 있는 데에 따른 것으로, 질 병의 인과성에 대한 전문성을 가진 양 학회가 국내외 문헌, 인과성 에 대한 최신의 과학적 논의 결과를 토대로 의견을 피력하는 것이 양 학회의 사회적 책무로 판단하였기 때문이다. 특히 담배소송 과 정에서 질병의 인과성 문제를 다루는 역학이라는 학문 분야의 가 치가 논의되고 있다는 점도 중요하였다. 특별위원회의 의견서가 향후 담배소송에서 보다 명료하고 과학적인 논의를 위하여 도움이 되기를 바란다.

<대한예방의학회 - 한국역학회 담배와 폐암 소송 관련 특별위원회 > 위원 명단(공동위원장 이하, 가나다 순)

조성일 공동위원장, 서울대학교 보건대학원 교수 서울대학교 보건환경연구소 소장 Journal of Preventive Medicine and Public Health 편 집위원장

[연락처: scho@snu.ac.kr, +82-2-880-2717]

김동현 공동위원장, 한림대학교 의과대학 교수 대한예방의학회 사회건강위원회 위원장

강영호 서울대학교 의과대학 교수 국제역학회지 편집위원 서울대학교 의학연구원 의료관리학연구소장

박순우 대구가톨릭대학교 의과대학 교수 한국학교보건학회 회장 한국건강증진개발원 담배규제실무자문단 청소년 분 과장

박은철 연세대학교 의과대학 교수 연세대학교 보건정책 및 관리연구소 소장

박형욱 대한의학회 법제이사

신민호 전남대학교 의과대학 부교수

신애선 서울대학교 의과대학 부교수
이강숙 가톨릭대학교 의과대학 교수

이선구 가천대학교 의학전문대학원 교수

정해관 성균관대학교 의과대학 교수

한국역학회 부회장

조홍준 울산대학교 의과대학 교수

대한금연학회 회장

지선하 연세대학교보건대학원 교수 연세대학교 국민건강증진연구소 소장 대한민국의학한림원 정회원

황승식 인하대학교 의학전문대학원 부교수 인천권역심뇌혈관질환센터 예방센터장

\section{REFERENCES}

1. Porta MS, Greenland S, Hernán M, Santos Silva ID, Last JM; International Epidemiological Association. A dictionary of epidemiology. 6th ed. Oxford: Oxford University Press; 2014, p. 1-343.

2. Rothman JK, Greenland S, Lash TL. Modern epidemiology. 3rd ed. Philadelphia: Lippincott Williams \& Wilkins; 2008, p. 1-758.

3. Gordis L. Epidemiology. 5th ed. Philadelphia: Elsevier/Saun-ders; 2013, p. 1-392.

4. Park S, Jee SH, Shin HR, Park EH, Shin A, Jung KW, et al. Attributable fraction of tobacco smoking on cancer using popula-tionbased nationwide cancer incidence and mortality data in Korea. BMC Cancer 2014;14:406.

5. Yun YH, Lim MK, Jung KW, Bae JM, Park SM, Shin SA, et al. Relative and absolute risks of cigarette smoking on major histo-logic types of lung cancer in Korean men. Cancer Epidemiol Biomarkers Prev 2005;14(9):2125-2130.

6. Jee SH, Samet JM, Ohrr H, Kim JH, Kim IS. Smoking and cancer risk in Korean men and women. Cancer Causes Control 2004;15(4): 341-348.

7. Proctor RN. The history of the discovery of the cigarette-lung cancer link: evidentiary traditions, corporate denial, global toll. Tob Control 2012;21(2):87-91.

8. Beyea J, Greenland S. The importance of specifying the un-derlying biologic model in estimating the probability of cau-sation. Health Phys 1999;76(3):269-274.

9. Siemiatycki J, Karp I, Sylvestre MP, Pintos J. Estimating the proportion of cases of lung cancer legally attributable to smoking: a novel approach for class actions against the to-bacco industry. Am J Public Health 2014;104(8):e60-e66. 